\title{
Bedømmelse af
}

gruppearbejde i

forbindelse med brug af

Cooperative Learning

som undervisningsmetode

Jens Ejbye Schmidt er lektor ved Institut for Miljø \& Ressourcer DTU og LearningLab DTU, og har gennem flere år arbejdet med at implementere undervisningsmetoden cooperative learning som laegger op til bedommelser af samarbejdskompetencer.

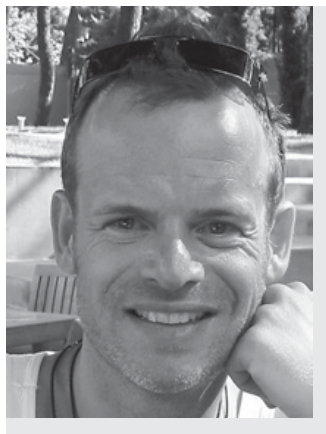

Jens Ejbye Schmidt er lektor på Institut for Miljø \& Ressourcer, DTU, hvor han i en årrække har undervist på fag for diplom- og civilstuderende. Han er medlem af studieudvalget på M\&R DTU, hvor han ligeledes er pædagogisk koordinator. Jens Ejbye Schmidt har bidraget til en række lærebøger indenfor miljøbioteknologi. Han har gennem det sidste år ligeledes været tilknyttet LearningLab DTU i forbindelse med et udviklingsprojekt omkring CL. Han fungerer endvidere som adjunkt-supervisor og pædagogisk konsulent på LearningLab DTU.

Cooperative learning (CL) er en undervisningsmetode, hvor lacing foregår $i$ små grupper (team), og interaktionen struktureres efter noje gennemarbejdede principper. Jeg har igennem en årrakke - og med succes - brugt CL $i$ min undervisning på Danmarks Tekniske Universitet. I denne artikel vil jeg beskrive det udviklingsarbejde, jeg har gjort med indforelse af CL, så der er en mere klar sammenhoeng mellem laeringsmål og undervisningsform, samt hvordan de studerende $i$ denne sammenhong bliver bedømt. Bedommelsen galder både deres faglige niveau, samt mere generelle ingeniørkompetencer.

\section{Baggrund}

Da jeg overtog kurset »Spildevandsrensning« på Danmarks Tekniske Universitet (DTU) bestod kurset af traditionelle forelæsninger, grupperegning, hjemme- opgaver og en fire timers skriftlig eksamen. Kun eksamensresultatet talte i den endelige bedømmelse. Jeg oplevede, at de studerende ikke opnåede de ønskede læringsmål efter at have fulgt kurset, f.eks. ved besvarelse af hjemmeopgaver, og at eksamen ikke var egnet til at teste, om de studerende havde fået en dybere forståelse af kursets indhold. Jeg mente derfor, at kurset trængte til en gennemgribende revision. I denne artikel vil jeg præsentere mit udviklingsarbejde i forbindelse med kurset mht. ændringer i læringsmål, undervisnings- og bedømmelsesmetoder, og baggrunden herfor.

\section{Overordnede ændringer}

Kursets læringsmål ændrede jeg for at tydeliggøre overfor de studerende, at der er to overordnede læringsmål ved kurset: et om spildevandsrensning og et om mere generelle bløde ingeniørkompetencer, såsom samarbejde, mundtlig og skriftlig kommunikation, forhandling, projektstyring og metodisk løsning af ingeniøropgaver (se faktaboks 1). I studieordningen på DTU er det specificeret, at de studerende udover de faglige kompetencer skal opnå generelle ingeniørkompetencer. En af de vigtige kompetencer er at kunne indgå i projektarbejde og kunne formidle stof både skriftligt og mundtligt. Som et led i revisionen indførte jeg ligeledes Cooperative Learning (CL) (Felder \& Brent, 1994) som den bærende undervisningsmetode (se nedenfor) og ændrede tilsvarende eksamensformen, for at få en bedre sammenhæng mellem kursets læringsmål (både de faglige og de generelle ingeniørmæssige) og form. Ændringerne blev godkendt af instituttets undervis- 
ningsudvalg. De studerende bliver i dag bedømt dels løbende gennem semesteret, og dels ved en skriftlig eksamen.

Jeg har afprøvet CL på 6 kursusforløb med i alt 289 studerende. Antallet af studerende på kurserne har været fra omkring 18 til 75 studerende.

\section{Kursusmål}

Den studerende forventes efter afsluttet kursus at have erhvervet dybtgående teoretisk forståelse for biologiske, kemiske og fysiske processer, som anvendes ved rensning af spildevand. Desuden erhverves kendskab til dimensionering af rensningsanlæg. Den studerende skal gennem casearbejdet også udvikle generelle ingeniørkompetencer.

\section{Kursusform - Cooperative Learning}

Den 15. juli 1982 var Donald Bennett den første amputerede person, som besteg det 4500 meter høje Mount Rainier i USA. Det tog ham fem dage. Da han bagefter blev spurgt om, hvad den vigtigste ting han havde lært af turen var, svarede han uden at tøve: "Du kan ikke gøre det alene«. De fleste undervisere accepterer formentlig Bennetts udsagn, men lærer studerende også optimalt i grupper, når de er i en undervisningssituation? Hvis jeg ser på de forskellige former for undervisningsforløb på universiteterne i Danmark, mener jeg, at underviserne strukturerer forløbet efter et eller flere af følgende principper:

- Den konkurrenceprægede situation - De studerende er i en tab - vind situation, de kæmper for at se, hvem der er bedst. Læring er set fra den enkeltes synspunkt en situation, hvor ens egen succes går ud over de andres. Konkurrence kan motivere nogle studerende til at arbejde mere energisk, men det som kendetegner konkurrencesituationen, er den negative afhængighed af andre studerende.

- Den individualiserede situation - De studerende arbejder uafhængigt af hinanden med deres egne læringsmål. I den situation er studerendes arbejdsmæssige målsætning ikke på nogen måde forbundet med fællesskabet.

- Den kooperative situation - De studerende arbejder i små grupper (team), hvor alle medlemmer kan mestre den givne opgave. Det centrale er at hjælpe andre og deltage aktivt $i$ et fælles projekt. Fællesskabet opnår ingen resultater, hvis ikke alle har løst deres opgave.

Hvilken situation er bedst? Ja, mange forskere (Johnson et al, 1990; Slavin 1990; Joyce, Weil \& Showers, 1992, Felder \& Brent 1994; Mills \& Cottell, Jr, 1998) er ikke i tvivl: den sidste. Studerende som arbejder i velfungerede grupper, lærer mere, får en dybere forståelse af det stof de arbejder med, færre stopper deres studier, de får en mere positiv indstilling overfor det emne de arbejder med, og de får større selvtillid, end når de arbejder individuelt eller i en konkurrencesituation.

Men alle disse fordele kommer ikke automatisk, når man som underviser bruger gruppearbejde som kursusform. Alle undervisere, som har prøvet gruppearbejde, ved også, at der ofte opstår en lang række problemer i forbindelse med det.

- Der er studerende, som laver lidt eller ingenting, og får den samme karakter som de øvrige i gruppen.

- Der er dominerende studerende, som laver det meste af arbejdet og på deres måde.

- Der er studerende, som ikke møder op af gode eller mindre gode grunde.

- Der er andre konflikter i gruppen.

Når sådanne problemer opstår, og gruppen ikke kan forstå eller ikke vil løse dem, vil de studerende måske være bedre tjent med at arbejde alene. Uheldigvis opstår sådanne situationer ofte og kan hurtigt komme ud af kontrol, hvis der ikke bliver gjort noget for at undgå dem. Problemet er, at de studerende ofte ikke har værktøjer til hurtigt at løse de problemer, som opstår.

En måde at imødegå gruppearbejdets klassiske udfordringer på er ifølge Felder \& Brent (1994) og Johnson et al. (1990) at anvende Cooperative Learning (CL). CL er læring i små team, hvor interaktionen struktureres efter nøje gennemarbejdede principper. Disse principper skal fremme ikke alene de studerendes faglige læring, men også udvikle deres intellektuelle og sociale evner. De studerende skal i fællesskab sætte sig nogle mål, som de derefter er sammen om at nå. CL lægger vægt på udvikling af argumentationsevne og personlige holdninger. Det forudsætter, at de studerende får et socialt læringsfællesskab, hvor alle studerende er aktive. Jeg har opstillet 6 principper baseret på Johnson et al. (1990) og Felder \& Brent (1994), som jeg bruger i CL (se faktaboks 2).

CL som pædagogisk idé er ikke ny. Sokrates underviste ved hjælp af tale, dialog og menneskelig interaktion. I dag findes der mange forskellige retninger under begrebet CL (Johnson et al. 1990; Slavin 1990; Joyce, Weil \& Showers, 1992; Felder \& Brent 1994; Mills \& Cottell,Jr, 1998). Hvis det skulle være en "opfinder« af begrebet CL og teorien bagved i moderne tid, må det være Morton Deutsch fra Teachers College, Columbia, forfatter til afhandlingen "Social Interdependence Theory« i 1949. En af hans elever, David Johnson, er i dag sammen med Roger Johnson leder af en forskningsenhed på University of Minnesota, som er ledende indenfor CL $\mathrm{i}$ ingeniøruddannelserne (Johnson et al, 1990). Senere har Richard Felder (North Carolina State University) brugt CL i forbindelse med aktiv læring på længerevarende uddannelser (Felder \& Brent, 1994). 
De 6 principper i Cooperative Learning (baseret på Johnson et al. 1990 og Felder \& Brent, 1994)

I. Positiv indbyrdes afhængighed. De studerende kan ikke løse opgaven alene, men er afhængige af de andres input for at løse den endelige opgave.

2. Individuel ansvarlighed. Alle er ansvarlige for at lave deres del af arbejdet og for, at de andre i gruppen også forstår det materiale, den enkelte arbejder med.

3. Interaktioner face to face. Dele eller alt arbejdet skal diskuteres og udføres sammen.

4. Brug af sociale kompetencer. De studerende i gruppen skal øve sig og få instruktion i ledelse, kommunikation, løsning af konflikter mv.

5. Lige deltagelse. Alle skal bidrage lige meget.

6. Selvevaluering af gruppen. Hvert medlem af gruppen skal løbende reflektere over, hvordan gruppen fungerer, hvad den enkelte kan gøre bedre, og om den enkelte skal gøre tingene anderledes i fremtiden. Denne selvevaluering kan indgå som et delelement i den endelige bedømmelse af den studerende.

\section{Cooperative learning - struktur og eksamen}

For at opfylde de forskellige principper i CL (se faktaboks 2), har jeg typisk formet undervisningen og eksamen på følgende måde: De studerende får 3 cases gennem semesteret med typiske ingeniøropgaver indenfor spildevandsrensningsområdet. De studerende arbejder i team på 3 til 4 personer. Grupperne danner jeg på baggrund af et spørgeskema, de studerende udfylder om deres faglige og personlige baggrund. Skemaet indeholder spørgsmål om den studerendes studieformål, gennemsnitskarakter, personlige data som køn, alder og nationalitet, fritidsinteresser, tider hvor de ikke har undervisning, en lang række faglige spørgsmål for at afklare deres kompetencer samt spørgsmål om deres læringsstil. Jeg tilstræber at lave heterogene team med komplementære kompetencer, f.eks. kunne jeg sætte en kemi- og en miljøstuderende sammen i en gruppe, da de har forskellig faglig baggrund.

Opgaven er så stor, at de studerende bliver nødt til at arbejde selvstændigt på delopgaver, men samtidig skal de studerende arbejde sammen for at fă lavet den endelige rapport (case). Efter 2 ugers arbejde afleverer de studerende den første version af deres rapport. Denne case evalueres af et andet team, som skriver 2-3 siders review. De studerende får en forelæsning om, hvad jeg forventer et review er. Efter at have modtaget

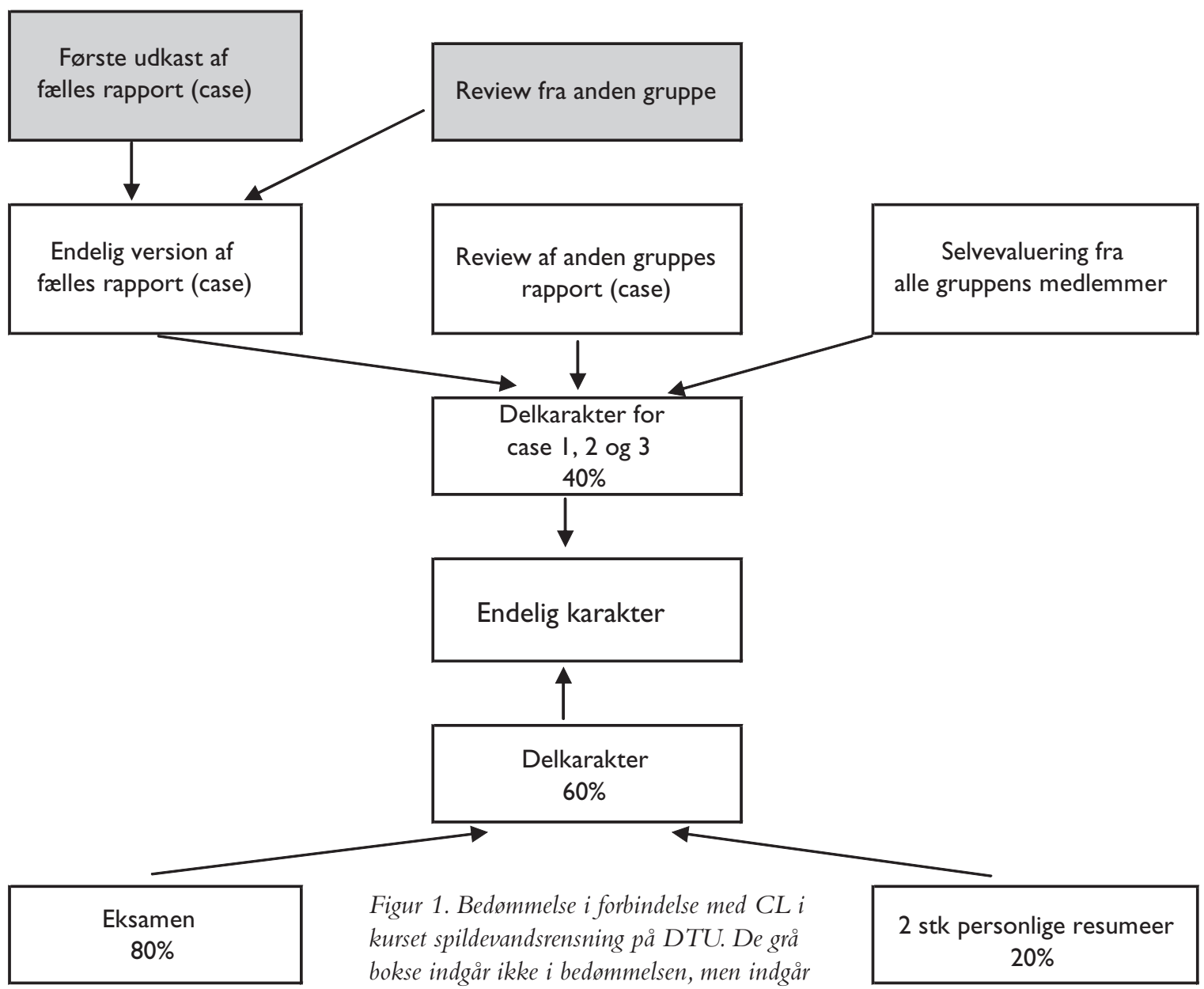

som input til de studerendes endelige produkt. 
dette review, har teamet en uge til at lave deres endelige version af deres rapport. Sammen med rapporten sender hvert medlem en selvevaluering af alle teammedlemmers arbejdsindsats - ink. sin egen - til mig (se næste afsnit). Hver studerende făr en delkarakter for hver rapport, som er baseret på deres fælles rapport, på selvevalueringerne fra alle gruppemedlemmer og på det review, teamet har lavet af en anden gruppes rapport (se figur 1). Desuden skal hver studerende indsende et personligt resume af hver case til mig.

Den endelige eksamen er en skriftlig 4 timers eksamen. Alle hjæelpemidler er tilladt. De studerende får udleveret en case som ligner de cases, de har arbejdet med i løbet af semesteret, men har mindre omfang. De studerende skal udvælge to af deres resumeer fra semestret og vedlægge deres besvarelse. Resumeerne skal vælges, så de bedst dækker de problematikker, de studerende har arbejdet med til eksamen. Karakteren for eksamen er baseret på svaret fra den studerende og de to vedlagte personlige resumeer (80/20). Casearbejdet tæller 40\% af den endelige karakter, mens den skriftlige eksamen tæller 60\% (se figur 1).

\section{CL - selvevaluering af gruppens arbejde og læring.}

Bedømmelse af læring styrer ofte de studerendes adfærd i semesteret (Millis \& Cottell, 1998). Derfor mener jeg, at det er optimalt, at bedømmelsen foretages med metoder, som fremmer mulighederne for at nå de givne læringsmål. Når man anvender en metode som CL og selvsagt andre undervisningsformer, kan man bedømme læringen og give karakter på forskellige måder. Det vigtige for mig er at anvende en metode til bedømmelse af CL, der forstærker og støtter udviklingen af den enkelte studerendes selvværd, læringsevne og udvikling af en positiv personlighed. Samhørigheden og den positive gensidige afhængighed mellem de studerende i gruppen kan forstærkes ved, at jeg indfører en alsidig bedømmelsesmetode i gruppearbejdet.

En uundværlig del af CL er, at de studerende evaluerer deres egen læring ved at reflektere over arbejdet i gruppen. Målet er at få de studerende til individuelt og i fællesskab at reflektere regelmæssigt over læringsprocessen. Dette har jeg gjort ved, at de studerende efter hver case afsætter tid, hvor teamet kan diskutere, hvordan det gik, samt hvad og hvordan man lærte. Jeg har valgt at give de studerende retningslinier til dette ved at opstille en række spørgsmål til gruppen og det enkelte medlem. Dette er gjort for at fă en god og alsidig evaluering fra de studerende. Dog er der ingen krav om at de skal følge disse.

De studerendes evalueringer skal give mening for de enkelte gruppemedlemmers selvfølelse og gruppens sociale adfærd og læringskvalitet. F.eks. er hensigten med spørgsmålet: »Hvordan fungerer gruppen, og hvordan kunne arbejdet forbedres yderligere?« at fă gruppen til at analysere og udvikle gruppens effektivitet gennem en fælles gennemtænkning af processen. De studerende skal evaluere alle 6 principper i CL og reflektere over, hvordan hver enkelt og gruppen har opfyldt principperne.

Her følger nogle eksempler på spørgsmål, som de studerende kan bruge til deres refleksioner over forløbet i gruppen:

\section{Eksempler på spørgsmål til gruppen}

- Hvad har vores gruppe udrettet?

- Hvad forsinkede vores arbejde eller hindrede os i at løse opgaven?

- Hvad skal der til for at gøre det bedre næste gang?

Eksempler på spørgsmål til den enkelte studerende

- Hvordan har jeg været til hjælp for gruppen?

- Hvordan har de andre gruppemedlemmer været til gavn for $\mathrm{mig} / \mathrm{min}$ gruppe?

- Det føltes virkelig rart for mig, da han/hun i min gruppe...

Hvert medlem giver deres vurderinger angående gruppen eller gruppemedlemmer inkl. sig selv, begrunder vurderingerne overfor de øvrige medlemmer af gruppen, og de øvrige medlemmer lytter. Teamets måde at fungere på diskuteres. Disse fremgangsmåder er efter min mening ikke alene en god hjælp til øvelse i at vurdere sig selv (selvkritik), men også $\mathrm{i}$ at give og modtage feedback. Refleksionerne skal udvikle de studerendes faglige og mere generelle ingeniørfærdigheder og sikre, at alle får feedback på deres handlinger. Efter at de studerende har selvevalueret i gruppen, sender hver enkelt studerende sine refleksioner/selvevaluering til mig på et præfabrikeret skema. Dette skema indeholder vurdering af hvert gruppemedlems indsats $i$ arbejdet. Vurdering går fra "utilfredsstillende« til "meget godt«. De studerendes evalueringer skal kun indeholde refleksioner over hver enkelt medlems niveau af deltagelse $\mathrm{i}$ gruppearbejdet, og grad af ansvarlighed. Den skal ikke afspejle deres faglige evner. Baseret på denne evaluering får hvert medlem af gruppen en personlig karakter, som dels afspejler gruppens faglige niveau (den afleverede rapport), og dels hver persons evne til at fungere $\mathrm{i}$ gruppen (de 6 principper), se figur 1.

\section{Læringsmål og bedømmelse understøtter hinanden}

Efter hvert kursusforløb har de studerende evalueret, dels med den generelle DTU evaluering, samt dels $i$ to tilfælde en udvidet evaluering, som jeg selv har udviklet til formålet. Derudover har der været tilknyttet en følgegruppe af studerende, som har diskuteret udviklingsarbejdet, og endelig har jeg sammenlignet eksamensbesvarelserne med læringsmålene før og efter 
indførelsen af CL. Nedenstående konklusioner er baseret på dette: De seks undervisningsforløb, jeg har gennemført på DTU, har vist, at de strukturer jeg bruger i CL, og den bedømmelsesform jeg benytter, er gode til at underbygge de læringsmål, jeg har med kurset, dvs. dels de faglige, dels de almene ingeniørmæssige (se faktaboks 1). De studerende bliver bedømt individuelt dels på det faglige, dels på deres evne til at indgå i et team med et fælles mål. Samtidig er eksamen blevet en naturlig del af læringsprocessen. Eksamen bliver ikke en hindring i læringsprocessen. Det er en del af arbejdet i teamet, at de studerende skriver deres refleksioner over gruppeprocessen ud fra de 6 principper, som jeg har opstillet, og de studerende bruger evalueringen på en positiv måde. Samtidig har strukturerne styrket gruppens samhørighed, så de studerende f.eks. oplever, at de har brug for hinanden, når de løser casen. Dette har også styrket det faglige udbytte af kurset for de studerende.

CL og tilhørende bedømmelse bør efter min mening ikke være den eneste undervisningsform på et universitet. Hvis man udelukkende anvender CL, er det en lige så dårlig løsning, som al anden ensidig anvendelse af en undervisningsmodel. Lærings- og bedømmelsesformer bør være varierede, fordi studerende har godt af at opleve forskellige situationer og arbejdsmåder i deres udvikling til alsidigt lærende. På DTU oplever de studerende $\mathrm{i}$ dag mange former for undervisning og bedømmelse, gående fra helt traditionelle (forelæsningerne) til mange nye typer. Dette vil give fremtidens ingeniører kompetencer som erhvervslivet ønsker: Både de generelle og de faglige.

Jeg arbejder for tiden med et udviklingsprojekt på LearningLab DTU, hvor jeg beskriver min egen praksis omkring CL. Resultaterne fra dette projekt håber jeg kan inspirere andre undervisere, når de ønsker at ændre et kursus' undervisningsform og tilhørende bedømmelse.

\section{Litteratur}

Felder, RM \& Brent, R (1994), Cooperative learning in technical courses: procedures, pitfalls and payoffs. Report to the national Science foundation (ERIC document reproduction no. ED 377 038)

Johnson, DW; Johnson, RT \& Johnson, HE (1990), Circles of learning. Cooperation in the classroom. Edina: Interaction Book Company. Joyce, B; Weil, M \& Showers, B (1992), Models of Teaching, Boston, Allyn and Bacon

Millis, BJ; Cottell, Jr., RG (1998), Cooperative learning for higher education faculty. Phoenix, AZ Oryx Press.

Slavin, R (1990), Cooperative learning, theory, research and practice. New York, Preager. 